\section{Novel market conditions and marketing consequences in the Hungarian guided hunting sector}

\section{What features characterise the domestic guided hunting market, where and how can the marketing concepts be utilised there?}

\author{
Zoltán Magyar \\ College of Nyíregyháza, \\ Faculty of Economic and Social Sciences, Nyíregyháza \\ magyarz@nyf.hu
}

SUMMARY

In Hungary the operating medium of game management and the guided hunting sector is undergoing such a radical change nowadays that on the one hand it considerably influences the profit-producing ability of the sector, and on the other hand it sets the actors of the industry new challenges and opportunities. If the Hungarian hunting industry, which has a traditional past, also wishes to preserve its position in this changed business medium, it is essential that the new situation be thoroughly assessed, and the value-oriented marketing attitude be adapted. The phenomena presented in this essay discuss the consequences and causes of the appearance of new service providers regarding the supply side, and the content changes of the consumer group and the modification of earlier consumption preferences and their causes on the demand side. The changing of the two media jointly generate the adaptation of the value-oriented service - marketing concepts, by using which the areas to be developed and deemed as the narrow cross-section of consumer decisions can be determined. After specifying the target group specific marketing properties of the aove-mentioned - prestige - service, such services of high utility content can already be established successfully that can be positioned as a proper alternative for the new consumer group of higher value expectation. On the other hand, the employment and profitability indexes related to this sector may considerably be improved.

Keywords: Hunting sector, Service marketing, Marketing activities, Consumer satisfaction

\section{INTRODUCTION}

Hungary's accession to the European Union has placed game management and the related services in an entirely new position, which is radically different from the earlier market conditions. It can be a potential benefit that the surplus production and income facilities arising from game management and the related tourism are not limited by the European Union either with quotas or other curtailments. It is a tendency of the sector that, as a result of the competitiveness pressure, the sales activity separates, becomes independent from production more and more, and the business branches evolving in this way (e.g. the guided hunting sector) already carry out their activity on the basis of a far more specific organising principle. The grounds of the production activity, in many cases invisible to the consumer, are also decided by the consumer's value judgment that comes into existence when a final, complex service is consumed. Thus, the proportion of services has increased both absolutely and relatively in the business sectoral structure of game management, and so it is not indifferent what standard and utility content the services provided by the companies offer to the consumers.

The question is what factors, what competences may be the source of a sustainable competitive edge on a strongly competitive service market. By the establishment and strengthening of what service attributes and performance factors may such value alternatives be created that are suitable for the satisfaction of the new and differentiated demands of the prestige consumer target group?

\section{CHANGING IN THE DEMAND AND SUPPLY SIDE}

Today game management and the hunting sectors are undergoing a radical change, which exerts an influence also on the related service elements gaining more and more ground in the sector.

In my essay, first of all I must clarify why a hunting sector having considerable and ruling traditions in the Hungarian agriculture requires the emphasising of the consumer-centric approach, as well as the adaptation of the a modern value (and not sales)oriented business attitude, and the service marketing concepts representing this.

The companies providing guided hunting services need the establishment and reconsideration of their activity's market and customer orientedness primarily by two strongly marked phenomena.

One of the phenomena appearing on the supply side is that Hungary's role as a "hunting great power" has seemed to cease to exist, or at least shattered for approx. 5 years. The Hungarian guided hunting facilities that used to be in a nearly monopolistic position are qualified by the world recorder feature of the shot game trophies, and the prestige type of the activity also recognised in international terms.

On the one hand, after the former Soviet member republics had become independent (Kazakhstan, Kyrgizstan, etc.), Yugoslavia had ceased to exist (e.g. by the establishment of Serbia, Croatia, Montenegro) and Poland, Rumania, Bulgaria had entered the 
market, such hunting fields developed, whose emergence has fundamentally reorganised the supply side of the market. Furthermore, the new members also offer hunting facilities deemed as curios such as the hunting of wolf, bear, lynx and quail. Another relative advantage is that when our country joined the European Union, the Hungarian trophy export was transferred from the VAT-free category to the $25 \%$ tax rate. The excess of expenditure realised this way can hardly be integrated into the price without the consequence of reduction in customer's loyalty. Therefore, the appearance of new competitors resulted in the opening, expansion of the supply side of the hunting market, and the effective operation in this new market medium requires us to reconsider our position.

The other phenomenon, which can be defined on the demand side but is a more complex aspect, comprises the trends of changes in the consumer, customer groups. The expansion of the Hungarian domestic basis of the hunting service is a strongly marked phenomenon, which originates from two main sources.

One of the trends has been present since 1990 and can be characterised in content terms as follows: Since the change in regime in 1989/90, hunting has become an alternative of social contacts, and even more, the potential scene of transacting businesses for certain members of the newly formed entrepreneurial, top managerial, political strata.

For them, the hunting activity is realised as some "sweet burden", since the motivation background of this activity does not necessarily imply the passionfeature. The pursuing of hunting does not require the rearrangement of their consumption structure, and, besides the above-mentioned factors, the prestige character arising from the social position and the belonging to the given reference group hides in the background of this activity. A reference group is the community of people representing values and norms and affecting the conduct of an actual or indirect member of the group (Hofmeister Tóth and Töröcsik, 1996).

Figure 1: Influence of the reference group on the purchasing decisions

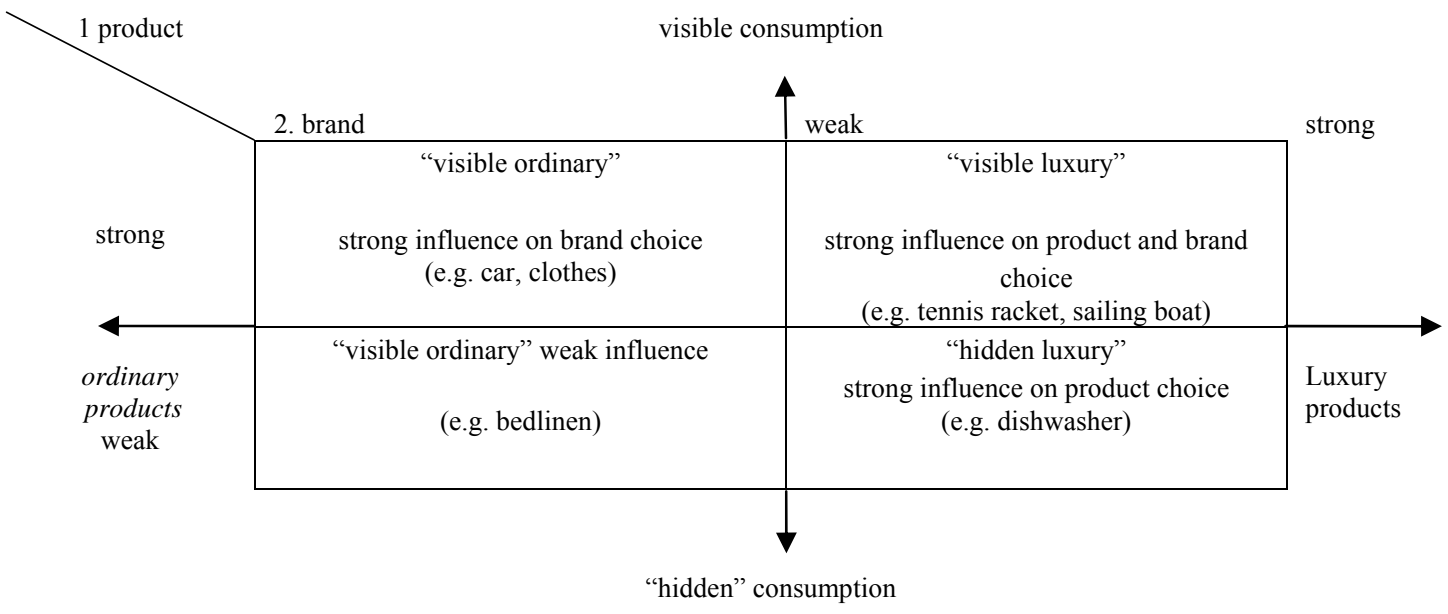

Source: Bearden and Etzel, 1982, in: Hofmeister Tóth and Töröcsik, 1996.

It can be seen that in this case of hunting the socalled "visible luxury" applies.

As for the free time habits of the above named group, "time pressure" and "experience seeking" as indentifiable motivation factors are accompanied by the relevant discretional income proportion. These factors lead to the phenomenon that the members of the target group wish to get an appropriate experience material during the short time expenditure.

Not only the process character of the service but also the result character gets in the dominant value perception position.

Furthermore, the new members of the consumer group can be characterised by the fact that, when exercising the consumer behaviour directed at the satisfaction of present needs, the output of the alternative seeking, evaluation and selection phases is largely determined by the past positive consumption experience of the members of the reference group.
This past positive consumption experience can be originated from the evaluation of hunting service already experienced and deemed as one having a proper utility content and appropriate standard.

This positive consumption experience on the one hand promotes the evolvement of consumer's loyalty, and on the other hand quickly spreads in a relatively "narrow range of clientele" by oral advertising. The creation, "providing" of the experience is such a potential possibility for the service provider that is based upon exact and detailed consumer knowledge and the customer-specific positioning of the service.

The other source of the expansion of the domestic scope of consumers is the appearance of such consumers wishing to hunt and pursuoing hunting activity who, if needed, in order to pursue the activity, are inclined even to temporarily or ultimately reorganise their consumption structure, as it is about the satisfaction of a strongly present, continuously renewing passion-like need. These two 
factors resulted in a considerable domestic potential expansion, thanks to which today approx. 56.000 sports hunters operate in Hungary.

Joining the new, increased consumer group presumes a considerable discretional income proportion owing to the luxury character of the activity, and thus the consumption of the guided hunting service is positioned as a relevant alternative for them.

\section{ACTORS AND TRENDS OF GUIDED HUNTING}

The actors of the guided hunting sector can well be identified, and thus the scope of persons pursuing this activity can be determined clearly. In this sector three main servicing groups can be distinguished.

1. Enterprises dealing with - individual - guided hunting, hunting organising that arrange shootings for foreign hunters in Hungary. These enteprises represent the strategic attitude focusing on service standard and consumer satisfaction in the most strikingly marked way. Their activity may involve conscious service standard planning, and satisfaction control.

2. Shooting parties consisting of domestic hunters where in most cases it is the members who hunt, but to cover the arising costs of the activity, both foreign and Hungarian guest hunters are offered guided hunting facilities.

The modern business strategic attitude only occasionally appears, since people do not realise its necessity or are not competent in this matter.

3. Companies that are mostly state-owned, have been operating for several decades and can be deemed as flagsips of the sector whose receipts nearly entirely arise from the guided hunting activity. They derive their successes, achievements from the traditions and the receipts arising from the loyal clientele coming back and back for several years.

Changes in the game management revenues of Hungary 1994-2005

\begin{tabular}{|c|c|c|c|c|c|c|c|c|}
\hline \multirow[b]{2}{*}{ Year } & \multicolumn{2}{|c|}{ Foreign } & \multicolumn{2}{|c|}{ Domestic } & \multirow[b]{2}{*}{ Live game } & \multirow[b]{2}{*}{ Shot game } & \multirow{2}{*}{$\begin{array}{c}\text { Other } \\
\text { revenues }\end{array}$} & \multirow[b]{2}{*}{ Total } \\
\hline & $\begin{array}{l}\text { Guided } \\
\text { shooting }\end{array}$ & Service & $\begin{array}{l}\text { Guided } \\
\text { shooting }\end{array}$ & Service & & & & \\
\hline 1994 & 2581456 & 391743 & 153424 & 108223 & 326715 & 761473 & 849524 & 5172558 \\
\hline 1995 & 3116725 & 506854 & 194344 & 104406 & 377110 & 1366529 & 919127 & 6585095 \\
\hline 1996 & 3205286 & 480075 & 289291 & 178130 & 597866 & 1883056 & 1110468 & 7744172 \\
\hline $1997 / 1998$ & 3431969 & 492055 & 678648 & 169172 & 571581 & 1572985 & 1702228 & 8618638 \\
\hline $1998 / 1999$ & 4165579 & 650659 & 854331 & 247168 & 577129 & 1609740 & 1574276 & 9678882 \\
\hline $1999 / 2000$ & 4897737 & 731126 & 1035222 & 251606 & 982992 & 275133 & 2104960 & 12078776 \\
\hline $2000 / 2001$ & 5502912 & 722854 & 1154021 & 351421 & 746680 & 2548700 & 1865253 & 12891841 \\
\hline $2001 / 2002$ & 5632647 & 658157 & 166910 & 403278 & 1000579 & 3040304 & 2365454 & 14769525 \\
\hline $2002 / 2003$ & 5980815 & 567313 & 1622539 & 453061 & 662562 & 2632691 & 2412607 & 14331588 \\
\hline $2003 / 2004$ & 5524435 & 544373 & 1690513 & 488921 & 446687 & 1941704 & 3103705 & 13740338 \\
\hline $2004 / 2005$ & 5376488 & 472209 & 2081003 & 424378 & 488065 & 2180408 & 3380608 & 14403159 \\
\hline $2005 / 2006$ & 4695822 & 366928 & 2249298 & 424539 & 615326 & 2306029 & 3781815 & 14439757 \\
\hline Change & $182 \%$ & $94 \%$ & $1466 \%$ & $392 \%$ & $188 \%$ & $303 \%$ & $445 \%$ & $279 \%$ \\
\hline
\end{tabular}

Source: National Game Management Data File

Table 2

Changes in the profitability of game management in Hungary from 1994 to 2006

\begin{tabular}{|c|c|c|c|}
\hline $\begin{array}{c}\text { Year of } \\
\text { hunting }\end{array}$ & $\begin{array}{c}\text { Revenues } \\
\text { (thousand } \\
\text { HUF) }\end{array}$ & $\begin{array}{c}\text { Expenditures } \\
\text { (thousand } \\
\text { HUF) }\end{array}$ & $\begin{array}{c}\text { Profit } \\
\text { (thousand } \\
\text { HUF) }\end{array}$ \\
\hline 1994 & 5172558 & 4723759 & 448799 \\
\hline 1995 & 658595 & 5817362 & 767733 \\
\hline 1996 & 7744172 & 7002778 & 741394 \\
\hline $1997 / 1998$ & 8618638 & 7693658 & 924980 \\
\hline $1998 / 1999$ & 9678882 & 9004354 & 674528 \\
\hline $1999 / 2000$ & 12078776 & 11220235 & 858541 \\
\hline $2000 / 2001$ & 12891841 & 12092634 & 799207 \\
\hline $2001 / 2002$ & 14769525 & 13580878 & 1188647 \\
\hline $2002 / 2003$ & 14311588 & 14038242 & 273346 \\
\hline $2003 / 2004$ & 13740338 & 14159570 & -419232 \\
\hline $2004 / 2005$ & 14403159 & 14256558 & 146601 \\
\hline $2005 / 2006$ & 14439757 & 13993830 & 445927 \\
\hline
\end{tabular}

Source: National Game Management Data File
To evaluate the results, we can compare the hunting revenues and the hunting expenses. Guided shooting means a considerable revenue. Its charge refers to the shooting charge determined by large companies with a hunting organising office and published on a price list. Of course, prices for trophic game are higher than the ones for the plain game. Pricing for the red deer, fallow deer and roe deer is based upon the antler mass, while for the wild boar upon the tusk length. The services mean the fee of the accompanying professional huntsman; and besides, the preparation and the judgement of the trophy, the overland car, the using of the team of horses and sledge, as well as the accommodation and board may be charged. When selling live game, the price is a question of bargain of the moment. Shot game refers to the game meat, whose price is determined by the demand-supply.

Other incomes comprise other sales (physical assets, etc.). The wages and the relevant public dues 
mean a considerable expense. Game management expenses, among others, include costs of the preparation of hunting facilities (feeding place, raised hide), providing forage, game agriculture, and game damages elimination. Other expenses may include the membership fee of organisations for the safeguarding of interests, commission of the hunting organising office, etc.

\subsection{Potential purposes, prospects}

Obviously, the marketing concepts and means cannot successfully be applied without defining the strategic attitude and the potential purposes.

The value increase of the guided hunting services can have the following potential purposes:

- To preserve and increase the level of receipts arising from guided hunting and the related services by establishing the satisfaction of the Hungarian and foreign guest hunters and maintaining their loyalty.

- Prolongation of the active service period, reduction of seasonality

- On the international market, restoring the prestige of the Hungarian hunting facilities, and by this, positive forming of the national image

- Improving the employment and profitability indexes related to this activity

- Improving the social judgement of the hunting activity.

\section{STRATEGY AND THE (SERVICE) MARKETING MEANS}

In the changed market competition environment, in the process of complying with the expectations of the new consumer groups, the urposes may be achieved by providing the relevant "value-response". This cannot be imagined without thoroughly understanding the consumer groups. According to Rekettye, it is not the objective value that is important but the perceived value, that is, the value acknowledged and accepted by the customers. (Rekettye, 1997). Therefore, one should focus on understanding the factors that actually mean a recognised value to us on the basis of the customer target group. According to the consumer conduct concepts regarding prestige consumption, a prestige product shall be defined as compared to the nonprestige product, based upon the perceived value components as follows:

- the perceived value of showiness: expression of the social status and wealth through a higher price,

- the perceived value of uniqueness: it shows the product's scope of possession and use,

- the perceived social value: it expresses the belonging to the reference group (Vigneron and Johnson, 1999).

The main characteristics of the consumer behaviour of prestige products and brands are as follows:

- low frequency of purchasing,
- the demand for information required for the purchasing decision is high,

- purchasing process of high interest,

- in the purchasing decision the following have an especially important role: organoleptic pleasures, intellectual incitement, social adjustment (Lehota, 2007).

In the first step of the value creating process, we should improve the ratio of the service price/value, and increase the standard of the service.

The adaptation of the marketing and customer-centric marketing concepts can be deemed as the narrow cross-section of the activity.

When studying the value-forming function of marketing, it may be ascertained that among experts several scientifically-founded opinions prove this, too.

The knowledge of consumer value preference, the production of value and the placement of this value at the customer's disposal can be considered the cornerstone of business marketing (Anderson-Narus, 1999, in: Mandják, 2005). According to Mandják (2005), the marketing processes include the activities of determining, establishing and forwarding of the value to be created for the customer.

When developing the conscious marketing activity of organisations offering guided hunting service, first we should examine the subject of the barter transaction, the so-called "service goods" between the seller and the customer, whose most characteristic feature in marketing terms is that it is a problem solution of non-physical character (Veres, 2005). As for the characterisation of the marketing properties of the services, the HIPI model summarising the properties may serve as a guide (Zeinthal et al., 1985, in: Veres, 2005).

\section{MARKETING FEATURES OF THE HUNTING SECTOR}

Therefore, during the marketing-centred characterisation of the guided hunting service and the determining of the elements to be developed, we should act on the basis of the HIPI principle.

Accordingly, the guided hunting service can (also) be characterised with the following features:

Heterogeneity: The performance of the service provider and the service standard experienced by the consumer are by nature fluctuant in time and space. This property is the consequence of the human factor. This phenomenon and its consequence obviously appear and largely contribute to the establishment of the final utility perceived by the customer. The guided hunting activity cannot be realised without the front-office staff directly taking part in the service process. This fact is a responsibility and an opportunity at the same time, as the human and professional preparedness, improvisation ability, flexibility, intelligence of the staff, that is, their manifesting customer-orientedness, largely promotes the establishment of the steady service-standard and the conscious quality positioning. However, if the above-mentioned competences are not present, the 
proper quality of the other service elements cannot compensate the decrease in service standard. Thus, the recognition and conscious handling of heterogeneity may be a key take-off point in the process of complying with the novel demands.

Intangibility: Since the services are experimental products, in our case no such goods sample is available to the customer on the basis of physical aspects that would make choice easier, and provide a further opportunity for the service provider to quality assurance. One of the most important tasks of the service provider is to make "the intangible tangible" (Kotler, 1998).

The creation and consumption of a service may already have physical results having a great value, in the present case the trophy, game meat, but for this, the customer must experience the service, that is, purchase it at least once.

From another aspect, these are very often "only" attendant circumstances of the service consumption, the experience of the event, the adventure is the primary expectation. This phenomenon is strongly differentiated in the various civilisations. The German-speaking guest hunters appreciate the unique, rare individuals of imposing trophy, and thus prefer the hunting of "quality" game. On the contrary, members of the Spanish, Italian clientele are not "trophy hunters," the trophy quality is only secondary to them, it is the number of individuals, the shooting of as many animals as possible that counts.

In our case, the lack of preliminarily available product sample upgrades the role of oral advertising. Relevant information provided by the members of the reference group may affect the consumer either when selecting the first service provider or when using further specifications.

Perishability: A further property of certain services is that if they are not consumed at a given time, such service may not be substituted, consumed later. It should be seen that this phenomenon is realised in a specific way in our case.

The guided hunting service, owing to the natural resources serving as the basis of its production, can originally be characterised by seasonality. A potential possibility of the guided hunting service providers is the prolongation of the service period, that is, to serve the consumers with such related services thanks to which the length of the inactive service period may be reduced. (For instance, most of the domestic areas offering big game hunting facilities are at the same time an excellent wine district, where thermal baths are also located. The South European guest hunters are very interested in Hungarian gastronomy.) The trophies realised as a result of the hunting activity, in certain cases in the amount of several million forints, are all tangible outputs of the activity. Another tangible output is the game meat, which is also very valuable.

Inseparability: The creation and consumption of the service are not separated in time but take place simultaneously. Thus, the front personnel are present and become important to the consumer at this time.
At this time, particularly during the hunting service, the quality of the service becomes known and is evaluated, without the possibility of subsequent corrections.

\section{CONSEQUENCES, TREATMENT OF THE FEATURES OF THE GUIDED HUNTING SERVICE}

Owing to the characteristics, Booms and Bitner (1981, in: Veress, 2005) supplemented McCarthy's classical 4P activity system with three elements (3P). The new elements should be defined in the case of the guided hunting service, too, since their character bears a key importance in the realisation of consumer satisfaction.

\section{People (human factor)}

Each person, especially the front office, participating in the establishment of the service and contributing to the final utility with his or her individual performance. In the present case, the organisers, realisers and attendants of the hunting. The heterogeneity depending upon their motivatedness largely affects the service value perceived by the customer.

\section{Physical evidence (physical elements)}

It refers to the medium, environment in which the hunting service is provided. In our case this factor also bears specific features.

The value of the hunting service is very often ensured by the extreme natural environment (safari, mountain hunting, tropical hunting). Considering these special elements, we should follow up the importance and influencing feature of the parametrisable factors (travelling, meals, accommodation, washing).

\section{Process (process feature)}

The guided hunting service comes to existence as a result of a process consisting of several steps.

It is a question whether the process feature of the service is realised as an inevitable concomitant or a value-increasing factor. We must see that in the case of the hunting service, rather the result feature than the process feature can be defined as a dominant value creator in the value preference of the new consumer groups of prestige motivation - owing to their consumer behaviour properties.

Certainly, this phenomenon does not entail the total undervaluing of the process feature but the revaluation thereof by the consumers.

Therefore, in the formation of a conscious marketing activity related to the guided hunting service, the following factors are determinant:

- The guided hunting service has an exclusive character, does not mobilise a huge clientele but presumes a relatively high discretionary income proportion

- The degree of choice freedom of customers using the service is high

- Owing to the little available time and high price, the risk perceived is high 
- The supply shows heavy seasonality

- The role of process type is replaced by the result type, the seeking of experiences

At the companies determining the markets of each industrial branch, the value offered to customers and interpreted in a novel way, as well as the complex value creating process are in the centre of the management's attention. This new phase, like the latest station in the development of marketing, has gotten in the developmental history of marketing by the name of the period of value orientation.

Accordingly, only such companies can expect leading market positions that lead in the production of corporate supply meaning an actual value to customers, which mean relatively more, other, more useful, so a larger value as compared with the competitors.

On the market of the different industrial sectors, market competition means who the consumer considers the worthy, "the most valuable" of his or her discretional income.

Today's intensive economic and social processes take effect also in sectors providing prestige services such as hunting. Owing to the intensive market competition, the Hungarian traditional hunting sector with a great past cannot be relieved from the thorough surveying of the new situation and the adaptation of the value-oriented business approach. The reorganisation of the supply side of the market was accompanied with the appearance of competitors, whose unique services are considerably able to "entice" the guest hunters and increase the expected value level.

Concurrently with this process, the value judgement of the consumer target groups against the services become more and more sophisticated, the demands get largely differentiated.

Adaptation to the new and complex circumstances in a way the present market positions can be preserved and strengthened is really a great challenge. However, this at the same time means an opportunity for the actors of this industrial sector. By obtaining knowledge about the market and customer environment, such information functioning as a narrow cross-section and - in the formation of the service supply - organising principle can be revealed that provide a framework for the strategic, consequent application of the marketing concepts if scientific standard. The service supply developed in this way and having an appropriate value content is already able to help the affected parties reach their precisely defined strategic purposes.

\section{REFERENCES}

Hofmeister Tóth, Á.-Törőcsik, M. (1996): Fogyasztói magatartás. Nemzeti Tankönyvkiadó, Budapest, 132.

Kotler, P. (1998): Marketing menedzsment. Müszaki Könyvkiadó, Budapest

Lehota, J. (2007): A szarvasgomba, mint luxusélelmiszer fogyasztói magatartása. AVA 3 - Agrárgazdaság: Vidékfejlesztés és Informatika Nemzetközi Konferencia, Debrecen, 2007. március 20-21.
Mandják, T. (2005): Marketing - Szemléletmód és Üzleti Kapcsolatok, Vezetéstudomány XXXVI. 5. 14-23.

Rekettye, G. (1997): Értékteremtés a marketingben. Közgazdasági és Jogi Könyvkiadó, Budapest

Veres, Z. (2005): Servicemarketing. KJK KERSZÖV Jogi és Üzleti Kiadó Kft., Budapest

Vigneron, F.-Johnson, L. W. (1999): A Review and a Conceptual Framework of Prestige - Seeking Consumer Behavior, Academy of Marketing Science Review, No.1 